\title{
Tobacco-Taking and Identity-Making in Early Modern Britain and North America
}

\author{
Angela McShane \\ Department of History, University of Warwick, UK \\ Email: a.mcshane@warwick.ac.uk
}

\begin{abstract}
This article explores the praxis of transatlantic snuff- and tobacco-taking and its importance to personal and national identity-making over the long eighteenth century. It focuses in particular on the role of snuff- and tobacco boxes, which uniquely provided white middling-sorts on both sides of the Atlantic with a socialized canvas upon which significant statements of status, personality, and sensibility could be made. However, a closer study of these objects during America's revolutionary period reveals stark contrasts in the social, political, and gendered meanings ascribed to tobacco-taking between Britain and America. The material evidence, it is argued, suggests that for men, and especially for women in revolutionary America, snuff- and tobacco-taking became almost synonymous with loyalty to the republic.
\end{abstract}

This article tracks shifts in tobacco-taking practices from the 1650s, when the tobacco habits of colonial America closely mirrored British and European manners, taste, and style, through to the American Revolution and its aftermath, when tobacco-taking was seen to frame the national identity of white, newly independent Americans. Fundamental to this analysis is the evidence provided by tobacco boxes that were made, owned, and used by mostly 'middling-sort' people in Britain and North America from the mid-seventeenth century to the early nineteenth. These everyday items were active participants in widespread practices of sociability that, as Andrew Sherratt has noted, "embod[ied] notions of status and value, as well as conceptions of identity and belonging, whether actual or desired ... in the competitive arena of social display'.

In what follows, these objects are positioned within the theoretical framework of praxeology, in which a social 'praxis' - a complex set of activities and

\footnotetext{
${ }^{1}$ Andrew Sherratt, 'Alcohol and its alternatives', in Jerome Goodman, P. Lovejoy, and A. Sherratt, eds., Consuming habits: drugs in history and anthropology (London, 1995), pp. 11-45, at pp. 12-13.

(C) The Author(s), 2021. Published by Cambridge University Press. This is an Open Access article, distributed under the terms of the Creative Commons Attribution licence (http://creativecommons.org/licenses/by/4.0/), which permits unrestricted re-use, distribution and reproduction, provided the original article is properly cited.
} 
behaviours that together demonstrate social knowledge - is distinguished from a simple 'practice', which is a single repetitive activity. Praxeology offers the historian a methodological model that moves beyond merely observing or describing practices, to understanding the shifts in social power that lie behind changes in social activity over time. The sociologist Andreas Reckwitz has helpfully summarized the elements of social knowledge that form a praxis (such as tobacco-taking) as 'a routinized type of behaviour which consists of several elements, interconnected to one another: forms of bodily activities, forms of mental activities, "things" and their use, a background knowledge in the form of understanding, know-how, states of emotion and motivational knowledge'. ${ }^{2}$ Reckwitz further argues that social agency is distributed right across the 'social communication network' of a praxis, so that 'things and their use' are as intrinsic to the formation, impact, and import of a social practice as are all the other emotional, intellectual, and gestural elements that he describes. This article accordingly examines the interactions between bodily and mental activities, know-how, emotional responses, and things and their use that were involved in taking tobacco on both sides of the Atlantic in the long eighteenth century, and argues that this praxis had an important part to play in the formation of personal and national identities.

Tobacco boxes have been popular with collectors since their inception in the seventeenth century and survive in relatively large numbers in both public and private hands. We know most about their operation in elite and courtly circles, where the design of boxes made of gold and silver, chased, painted, enamelled, and bejewelled by famous artisans, and the details of their commission or exchange, were often the subject of gossip. ${ }^{3}$ But it was not only the rich and fashionable in early modern society who valued their tobacco boxes enough to treasure them for posterity. Collections today also preserve a bewildering array of mundane pop-u-luxe and factory-made creations of wood, horn, copper, brass, and steel. ${ }^{4}$ These more ordinary tobacco boxes embody a gamut of professional and amateur skills and techniques, as well as production and distribution systems.

The small group of seven boxes pictured in Figure 1 exemplify how these objects might supply evidence of praxis, as defined above. All seven were factory- or workshop-made from common materials and to common patterns. Each box has been personalized for one male owner, all of whom were fond of tobacco (the boxes have seen much use). All seven owners had 'know-how' as

\footnotetext{
${ }^{2}$ Andreas Reckwitz, 'Toward a theory of social practices: a development in culturalist theorizing', European Journal of Social Theory, 5 (2002), pp. 243-63, at p. 249.

${ }^{3}$ See, e.g., Clare Le Corbeiller, European and American snuff boxes, 1730-1830 (New York, NY, 1966); Deborah Gage and Madeleine Marsh, Tobacco containers and accessories: their place in eighteenthcentury European social history (London, 1988); Heike Zech, Gold boxes: masterpieces from the Rosalinde and Arthur Gilbert collection (London, 2015).

${ }^{4}$ See, e.g., John Bedford, All kinds of small boxes (London, 1964); Edward H. Pinto, Treen and other bygones (London, 1969), pp. 326-56; Daniëlle O. Kisluk-Grosheide, 'Dutch tobacco-boxes in the Metropolitan Museum of Art: a catalogue', Metropolitan Museum Journal, 23 (1988), pp. 201-31; Clare Walsh, 'The advertising and marketing of consumer goods in eighteenth-century London', in C. Wischermann and S. Elliott, eds., Advertising and the European city: historical perspectives (Aldershot, 2000), pp. 79-95.
} 


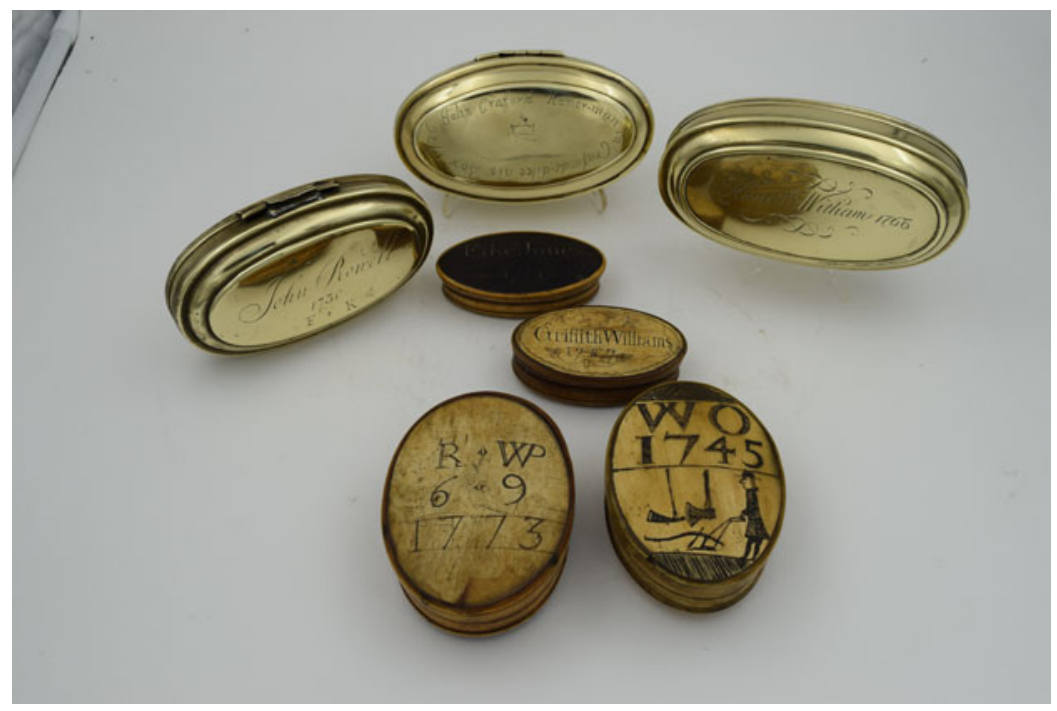

Fig. I. Back row: brass tobacco/snuffbox, hinged, inscribed 'John Rowell / 1730 / F*K'; brass tobacco/ snuffbox, hinged, inscribed 'John Craford Hamer-Man in Crafords-dike his Box 1726' and 'Woman and Wine will now / and then decive of Some wise / Men'; brass tobacco/snuffbox, inscribed 'Henry Witham 1768'. Middle row: horn snuffbox, inscribed 'Edw. Jones 1799'; horn snuffbox, inscribed 'Griffith Williams 1787'. Front row: horn tobacco/snuffbox, inscribed: 'RWP 69 1773'; horn tobacco/snuffbox, inscribed: 'W O 1745'.

Source: Image courtesy of the Bryan Collection. Photo: Tom Gleason.

consumers, because the more expensive brass boxes have well-fitting lids, ideal for carrying around, while the horn boxes, though made of the cheapest material on the market, were best suited for keeping snuff fresh and fragrant. ${ }^{5}$ We also know that each owner's family treasured these personal artefacts after the owner's death, because they have survived for hundreds of years.

Although for most of the boxes in the group we now know little more than an owner's name or initials and (probably) the year in which the box was bought or gifted, they all nevertheless afford more complex evidence of identity, gesture, and emotional networks. For example, John Rowell's box was gifted by a now anonymous friend, with the initials ' $F$. K.' The carving on 'W. O.'s horn box revealed his identity as a ploughman (or a farmer), his pride in his trade being declared to the company he kept whenever he took his box from his pocket. About the Scotsman John Craford, we know much more. Using words, rather than images, to identify his pride in being a 'hamerman' (a metalworker), perhaps 'his box' signalled the end of his apprenticeship in 1726. But Craford was equally proud of his namesake town, Cra[w]fords $\mathrm{D}[\mathrm{y}] \mathrm{ke}$. In 1700 , the town imposed a local tax on beer in order to raise the money to build a harbour. The work, which necessarily involved many skilled metalwork trades, began in 1707. By 1740, Crawfords Dyke had been transformed

\footnotetext{
${ }^{5}$ Paula Hardwick, Discovering horn (Guildford, 1981).
} 
from a tiny fishing village into a thriving town. ${ }^{6}$ The growing confidence of his hometown was matched by Craford's own desire to perform well in social situations. While his box lid made a statement of identity, the base demonstrated his wit and social worth. An inscription - 'Woman and Wine will now and then decive [sic] of Some wise Men' - was placed where it would only be seen by friends who handled the box. This general moral had specific relevance for the locality, where beer, not wine (or women), had brought prosperity to Craford and Crawfords Dyke alike.

As these few examples show, far from being silent functionaries in the "competitive arena of social display', tobacco boxes 'spoke' through a visual and textual vocabulary of lively scenes, mottos, and exhortations. Common practices of personalization and inscription transformed many ordinary boxes into a form of life-writing, as well as helping to locate them precisely in time, place, and social context. Yet, while personalized, everyday objects such as these can be extraordinarily valuable in revealing the 'social communication network' in which the praxis of early modern tobacco-taking was entangled, it is important to note that most surviving boxes are neither dated nor inscribed, and that it was very rare for early modern people to discuss or even comment upon their everyday use of tobacco. ${ }^{7}$ In consequence, for the historian to understand shifts in material meaning and use over time, they must draw from an eclectic mix of material, literary, and documentary sources, and gain the greatest possible sense of the huge variety of shapes, designs, and uses to which tobacco boxes were put, over a long period.

Central to this article is a database of several hundred extant and nonextant but contemporaneously recorded British- and American-owned tobacco boxes, dating to the period between 1650 and the early 1800s. The extant object database has been garnered from a large number of curatorial, auction house, UK and US national, state, and provincial decorative and fine arts museum catalogues, both printed and digital. I have also handled and researched three important collections in person. The first, a large private collection of early modern objects, includes dozens of tobacco boxes that were made for and owned by British people, mostly of the 'middling sort'. ${ }^{8}$ The second, a significant collection of American-made and -owned boxes, is held in the Yale University Art Gallery. ${ }^{9}$ The third, a collection of quotidian

\footnotetext{
${ }^{6}$ George Chalmers, Caledonia: or, an account, historical and topographic, of north Britain (4 vols., Edinburgh, 1890), III, pp. 806-9.

${ }^{7}$ Ian Hodder, Entangled: an archaeology of the relationships between humans and things (Chichester, 2012).

${ }^{8}$ I am especially indebted to the late John H. Bryan II, curator Dru Muskovin, and curator/photographer Tom Gleason, for their generous support, inspiration, and help. For a partial catalogue of the Bryan Collection, see Edward Town and Angela McShane, eds., Marking time: objects, people, and their lives, 1500-1800 (New Haven, CT, 2020).

${ }^{9}$ I am grateful to Yale University Art Gallery's senior curator, Patricia Kane, for allowing me access to the collection and generously sharing her expertise. See Patricia E. Kane, Colonial Massachusetts silversmiths and jewelers (New Haven, CT, 1998); John Marshall Phillips, Masterpieces of New England silver, 1650-1800 (Boston, MA, 1939); Kathryn C. Buhler and Graham Hood, American silver in the Yale University Art Gallery (2 vols., New Haven, CT, 1970).
} 
boxes dating to the late eighteenth to late nineteenth century, was amassed by Sir Henry Wellcome. ${ }^{10}$ As noted above, the majority of surviving boxes were neither dated nor inscribed; even when there are clear signs of gifting, as with John Rowell's box, the likely gender of givers and recipients can be very uncertain. ${ }^{11}$ The sometimes explicit and sometimes oblique evidence that the material sources can supply has been augmented and contextualized by drawing upon a wide range of contemporary textual and visual sources, including depositional and probate records, personal diaries and correspondence, treatises, periodicals, printed images, and painted portraits, both on canvases and on box lids.

The article first outlines the development of tobacco-taking practices in Britain over the long eighteenth century. The focus then shifts to the role of tobacco boxes, which provided white middling-sorts on both sides of the Atlantic with a socialized canvas on which significant statements of status, personality, and sensibility could be made. We see how, on one hand, inscriptions make past ownership and identities explicit, while, on the other, the designs and patina impressed upon extant objects through everyday practices of use, adoption, and adaptation uniquely evidences their place in gestural and emotional experience. However, a close study of objects from both sides of the Atlantic also reveals stark contrasts between Britain and America in the social, political, and gendered meanings ascribed to tobacco-taking in the period of the American Revolution. These contrasts, and their implications at this key moment in the formation of America's national identity, provide the article's final theme.

\section{II}

Scholars agree that 'drinking' tobacco was not only a socially widespread practice by the mid-seventeenth century, but that it was a 'panacea for [early] modern living', a source of physical and psychological comfort that could ease exhaustion, alleviate hunger, and lift a person's mood. ${ }^{12}$ At the same time, the manners and materials of tobacco-taking played an increasingly central role in the 'social communication networks' underpinning the various

\footnotetext{
${ }^{10}$ Stewart Emmens, senior curator at London's Science Museum, very kindly aided and abetted my encounter with this characteristically quirky but barely catalogued collection.

${ }^{11}$ See Angela McShane, 'Bad habits and female agency: attending to early modern women in the material history of intoxication', in Merry Wiesner-Hanks, ed., Challenging women's agency and activism in early modernity (Amsterdam, 2021), pp. 25-63, at pp. 38-48.

12 Jordan Goodman, Tobacco in history: the cultures of dependence (London, 1994), ch. 3; Jason Hughes, Learning to smoke: tobacco use in the West (Chicago, IL, 2003), ch. 2, esp. pp. 42-8; Beverly Lemire, Global trade and the transformation of consumer cultures (Cambridge, 2018), ch. 5, esp. pp. 198-9; Andrew Rowley, 'How England learned to smoke: the introduction, spread and establishment of tobacco pipe smoking in England before 1640' (Ph.D. thesis, York, 2003); A. G. Taylor, 'Venting smoke: the trade and consumption of tobacco in early modern England and Wales, c. 1625-1685' (Ph.D. thesis, Sheffield, 2018); idem, 'Tobacco retail licences and state formation in early modern England and Wales', Economic History Review, 72 (2019), pp. 433-58.
} 
formations of 'company' - in civic, legal, trade, and social contexts - that were so essential to early modern society. ${ }^{13}$

Framing an acceptable praxis for tobacco-taking and developing systems for policing its social and material parameters presented problems for highly ritualized early modern societies. The modes and manners of alcohol consumption were based upon a deeply entrenched and widely understood canon of narratives drawn from classical and religious authorities, which clearly delineated behavioural models for creating social cohesion, differentiation, or division. ${ }^{14}$ But new intoxicants, such as tea, coffee, and tobacco, or popular new adaptations - such as snuff and gin - required the development and dissemination of novel routines, rituals, and choreographies of words, gestures, and things. ${ }^{15}$

In one pamphlet, a fashionable 'beau' expressed his pity for the ancients, because their ignorance of tobacco condemned them to being not only intellectually, economically, and materially backward, but also incapable of meaningful social communication:

Being without it spoilt all their Wit, Judgment, and Industry; for Consequently they could have no Tobacco-Boxes, Tobacco-Stoppers, or Snuff-Boxes; all which are the Tests, and Indications of a Mans Genius. A Large Tobacco-Box shows a Man of Great and Extensive Trade and Conversation, a small one well Japan'd, shows a Gentleman of good Humour, that would avoid smoaking for the sake of the Ladies; and yet out of Complaisance does it to oblige the Persons he Converses with. So as to Stoppers, if made of the Royal-Oke, it shows Loyalty; Glastenbury-Thorn, Zeal extraordinary: a Piece of Pipe, Humility: Silver, Pride; Black-thorn, Adversity: And the use of the little Finger, if the Pipe be well lightn'd, great Patience. ${ }^{16}$

Though satirical, the passage nonetheless contained an important element of truth. Failing the ancient traditions on which alcohol could rely, delineating the praxis of tobacco-taking, and the respectability of the tobacco-taker, depended instead upon a combination of contemporary structures and

\footnotetext{
${ }^{13}$ Phil Withington, 'Intoxicants and society in early modern England', Historical Journal, 54 (2001), pp. 631-57; idem, 'Public discourse, corporate citizenship, and state formation in early modern England', American Historical Review, 112 (2007), pp. 1016-38.

${ }^{14}$ Phil Withington and Angela McShane, eds., Cultures of intoxication, Past \& Present, 222, Suppl. 9 (2014), esp. Robin Osborne, 'Intoxication and sociality: the symposium in the ancient Greek world', pp. 34-60; Jennifer Richards, 'Health, intoxication, and civil conversation in Renaissance England', pp. 168-86; and Angela McShane, 'Political and material cultures of drinking in seventeenthcentury England', pp. 247-76. Also David Hancock, Oceans of wine: Madeira and the emergence of American trade and taste (New Haven, CT, 2009), pp. 341-92.

${ }^{15}$ Withington, 'Intoxicants and society'; McShane, 'Political and material cultures of drinking'; Matthew Romaniello, 'Who should smoke? Tobacco and the humoral body in early modern England', Social History of Alcohol and Drugs, 27 (2013), pp. 156-73. See also Kimberley Hockings and Robin Dunbar, eds., Alcohol and humans: a long and social affair (Oxford, 2019).

${ }^{16}$ William King, Dialogues of the dead (London, 1699), pp. 63-4.
} 
influences. These included customary conventions of 'fellowship', 'company', politeness, and taste; civic policy and legal enforcement; industrial systems of production and retail; and the press, which tracked change, mediated debate, and disseminated know-how, judgement, and ideas. These new 'authorities' competed to provide answers to the principal praxeological questions: who should consume tobacco? Where and when should they consume it? With what, and in what manner should it be consumed? And, finally, what were the broader social implications if these newly established routines and rituals of behaviour were breached?

Regarding class, gender, and age, the question of who should respectably consume tobacco was highly contingent upon geography. As Alex Taylor shows, in English regions connected to the maritime trade, such as the West Country and the West Midlands, tobacco-taking was a universally accepted practice. ${ }^{17}$ In 1666, a French traveller, M. Jorevin de Rochefort, described his experience of staying at the Stag Inn at Worcester, where he was encouraged to dine with the family:

the supper being finished [his hosts] set on the table half a dozen pipes and a packet of tobacco for smoking, which is a general custom as well among women as men, who think that without tobacco one cannot live in England, because, say they, it dissipates the evil humours of the brain. ${ }^{18}$

Describing William III's journey through the West Country towards London in 1688, the Dutchman Constantijn Huygens noted: 'we saw country folk everywhere ... [including] five women, all chewing tobacco [who] greeted [William]. Indeed, we saw many women smoking without shame, even young girls of thirteen or fourteen. ${ }^{19}$ Though one of England's poorest regions, Cornwall experienced particularly high levels of smoking. ${ }^{20}$ On describing her visit there in the 1690s, the diarist Celia Fiennes remarked: 'the Custome of the Country ... is a universall smoaking, both men women and children have all their pipes of tobacco in their mouths and soe sit round the fire smoaking, ${ }^{21}$ Nevertheless, in most parts of Britain, pipe-smoking by women in public places was often subject to criticism. ${ }^{22}$

The age at which early modern people began smoking is uncertain. In 1702, the Leeds antiquary Ralph Thoresby, while at Garraway's coffeehouse, noted seeing his brother's 'sickly child of three years old fill its pipe of tobacco and smoke it as audfarandly [sic] as a man of three score'. ${ }^{23}$ Contemporary text-

\footnotetext{
17 Taylor, 'Tobacco retail licences'.

${ }^{18}$ Quoted in G. L. Apperson, The social history of smoking (London, 1914), pp. 211-12.

${ }^{19}$ Rudolf Dekker, ed. and trans., The diary of Constantijn Huygens Jr secretary to Stadholder-King William of Orange (Amsterdam, 2015), p. 58.

${ }^{20}$ See Mark Overton, Jane Whittle, Darron Dean, and Andrew Hann, Production and consumption in English households, 1600-1750 (London, 2004), p. 117.

${ }^{21}$ Christopher Morris, ed., The illustrated journeys of Celia Fiennes, c.1685-c.1712 (London, 1982), p. 204.

22 See McShane, 'Bad habits', pp. 29-38.

${ }^{23}$ Quoted in Apperson, Social history of smoking, p. 92; see also ch. 5.
} 
books suggest that some middling-sort boys may have commenced at school, while early American portraits and snuffbox inscriptions offer some limited evidence of teenage girls legitimately taking snuff. ${ }^{24}$ Not everyone started so young, however: John Cannon, a man from the West Country, successfully avoided the habit until, in 1709 , at the age of 25 , he began work as an exciseman. His new employer 'importuned me to smoak tobacco saying it would be more agreeable to him if I learned to smoke, not failing to set forth that noble qualification in \& towards company keeping'. Cannon relates the grim tale of his attempts to induct himself into the smoking fraternity overnight, after which his room 'resembled a jakes or a bog house'. Having finally become 'a master of that art', he 'wished many times afterwards I had been without this qualification which serves only to consume money \& time \& dries up the radical moisture of nature. ${ }^{25}$

In an age of growing politeness, the question of where and when tobacco could be respectably smoked was particularly important, since smoking imposed a veritable onslaught on the senses. Not only a pungent activity, it was also inevitably accompanied by the sounds and sights of spitting, which even the most attractively decorated spittoon could not alleviate. ${ }^{26}$ Solitary or companionable smoking in the privacy of the home was regarded as an unimpeachably peaceful and orderly domestic activity for both men and women. ${ }^{27}$ For men, sociable smoking in alehouses, inns, and taverns was perfectly acceptable, while the coffeehouse was unthinkable without tobacco smoke. $^{28}$

Yet smoking was not always tolerated in public, civic, or social spaces. In Norwich, local officials decided that it was not permissible in the streets and charged offenders accordingly. ${ }^{29}$ Though many among the clerical and legal professions were tobacco-takers, smoking was unwelcome in churches or courts, in the houses of parliament, and in the royal presence. ${ }^{30}$ Breaches of these conventions reflected badly on the miscreants. For example, an oftenrepeated story of Charles I's captivity told how parliamentary soldiers deliberately smoked in the king's presence and blew smoke in his face, indicating a brutish disregard of his person and authority. ${ }^{31}$ Magistrates often met in the upstairs rooms of taverns or inns, but they were expected to go to a separate room to 'refresh themselves' with drink and tobacco. One contempt of court case revolved around the question of whether the magistrates had been taking

\footnotetext{
${ }^{24}$ See Charles Hoole, An easie entrance to the Latin tongue (London, 1649), p. 167; American School, Portrait of Abigail Rose at the age of fourteen, North Branford, CT, 1786, www.skinnerinc.com/auctions/2567B/lots/293.

${ }^{25}$ John Money, ed., The chronicles of John Cannon, part I (Oxford, 2010), p. 93.

${ }^{26}$ Goodman, Tobacco in history, pp. 83-4.

${ }^{27}$ McShane, 'Bad habits', pp. 33-4.

${ }^{28}$ See Brian Cowan, The social life of coffee (New Haven, CT, 2005), pp. 86, 103, 133, 166, 181, 226-7.

${ }^{29}$ Mayor's court book, 1666-77, case 16a/24, 13 May and 27 June 1674, Norfolk Record Office, fos. 275r, 281v.

${ }^{30}$ Thomas Edwards, The third part of Gangraena (London, 1646), pp. 252-3; Bedford, All kinds of small boxes, p. 17.

${ }^{31}$ See, e.g., George Bates, Elenchus motuum nuperorum in Anglia (London, 1685), pp. 150-1.
} 
tobacco at the time of the confrontation, in which case they were deemed to be not 'in session'. 32

Smoking was also restricted in polite mixed company. A gentleman was expected to ask the ladies, or wait to be invited, before indulging himself with a pipe at social gatherings. In 1745 Elizabeth Montague (an avid snufftaker) described how Dr Young, a Tory vicar,

came after the meal was over, in hopes of smoking a pipe; ... I saw a large horn tobacco box, with Queen Ann's head upon it, peeping out of his pocket, but I did not care to take the hint, and desire him to put in use that magnificent piece of furniture. ${ }^{33}$

Smoking during meals was also unacceptable for polite gatherings, though after dinner men and women parted company, allowing the men to drink wine or punch, the women to drink tea, and both to take tobacco. ${ }^{34}$

By the mid-seventeenth century, it was already the case that social smoking obliged men of all classes to share their tobacco with the assembled company and, in the process, to display their personal smoking paraphernalia. But the conventions that governed sociable smoking were revolutionized by the widespread adoption of snuff-taking. Scotland, which was a centre of manufacture, was early in adopting the habit, but snuffing was introduced relatively late to English and British-American society. ${ }^{35}$ Moreover, it came via continental social elites, complete with an already well-established code of sophisticated manners, materialities, and gestural and conversational intercourse. ${ }^{36}$ Snuffing began to appear regularly on the London stage and in print from the $1670 \mathrm{~s} .{ }^{37}$ As it was denigrated and satirized as a fiddly, foreign, and foppish fashion, young men (dubbed 'beaus') who snuffed were accused of adopting feminized interests in decorative dress and social gossip, while women were

\footnotetext{
32 'Office of the Judge $v$ Edward Freeman of Blockley, co. Worcester, gent, June 1637-February 1638', in Richard Cust and Andrew Hopper, eds., The Court of Chivalry 1634-1640, British history online, http://www.british-history.ac.uk/no-series/court-of-chivalry/472-office-of-the-judgefreeman.

${ }^{33}$ Matthew Montagu, ed., The letters of Mrs. E. Montagu: with some of the letters of her correspondence (4 vols., London, 1809-13), III, p. 340.

${ }^{34}$ Berthold Laufer, 'Introduction of tobacco into Europe', Field Museum of Natural History, Anthropology Leaflet, 19 (1924), pp. 1-66, at p. 28; See, e.g., Michael Stevens and Honor Lewington, eds., Roger Whitley's diary, 1684-1697 (2004), entry for Sept. 1684, https://www.british-history.ac.uk/no-series/roger-whitley-diary/1684-97/september-1684, and passim; Ferdinand Bayard, Travels of a Frenchman in Maryland and Virginia, with a description of Philadelphia and Baltimore, in 1791, ed. and trans. Ben C. McCary (Williamsburg, VA, 1950), p. 147.

${ }^{35}$ Robert C. Nash, 'The English and Scottish tobacco trades in the seventeenth and eighteenth centuries: legal and illegal trade', Economic History Review, n.s. 35 (1982), pp. 354-72; Dennis Gallagher, 'Snuff is enough: tobacco consumption in eighteenth-century Scotland', Journal of the Académie Internationale de la Pipe, 8 (2015), pp. 109-14.

${ }^{36}$ See, e.g., Corbeiller, European and American snuff boxes.

${ }^{37}$ See, e.g., Francis Fane, Love in the dark (London, 1675); Aphra Behn, The feign'd curtizans (London, 1679); Thomas Durfey, Squire Oldsapp (London, 1679).
} 
rebuked for the unwomanly filthiness and unwonted independence that the habit engendered. ${ }^{38}$

At first, periodical writers lumped snuffing together with other short-lived crazes and expected the passion to pass. ${ }^{39}$ Disputations over whether snufftaking was a threat or a benefit to health were printed on both sides of the Atlantic. One striking passage calculated its negative impact on national resources of time and energy. ${ }^{40}$ But neither medical nor economic detractors could restrain the snuffing habit. From the 1720s, it was being enthusiastically embraced right across society. ${ }^{41}$ The ever-expanding periodical press shifted from attacking the habit to mediating, disseminating, and policing its praxis. A vast array of printed matter-articles, books, pamphlets, and pictures described, depicted, and dictated the social 'rules' surrounding snuff-taking, and explained why they mattered. ${ }^{42}$

Despite occasional criticism from the pulpit or in the press, and unlike smoking, it was socially acceptable for any adult to take snuff, at any time, and in any place. It was often prescribed as a way of punctuating polite conversation, promoting a more measured and thoughtful manner of discourse. ${ }^{43}$ offering, or requesting, a pinch of snuff was a licit and sober way of commencing conversation between strangers of either sex, while denying a request for, or turning down an offer of, snuff came to be seen as reprehensible behaviour. Lady Montague complained of the 'miserable stuff people carry about in their pockets ... and you cannot refuse ... taking a pinch' ${ }^{44}$ Like smoking, snuffing had its physical downsides, not least sneezing, continual sniffing, and dirty-looking nostrils, lips, fingers, and clothing. ${ }^{45}$ But it presented nothing like the same impolite intrusion as smoking. Snuff was delicately fragrant for both the taker and the bystander, it could be adapted to individual tastes, and a moderate, well-managed taker could amend any visual disadvantage through the judicious use of attractive handkerchiefs. Meanwhile, the ubiquitous snuffbox, a perfect fit for the new-style pockets in both men's and women's wear, provided a universally understood vehicle for statements of social and political identity, for interactions with kith and kin, for promoting friendships with a wide social network, and for expressing all kinds of emotions.

III

Central to the praxis of tobacco-taking were the objects that enabled its routines and rituals. The bare essentials that a smoker needed - a clay pipe, a

\footnotetext{
${ }^{38}$ See, e.g., Tatler, 28-30 Jun. 1709; Spectator, 19 Apr. 1711.

${ }^{39}$ The history of the works of the learned (4 vols., London, 1699-1703), IV, p. 220.

${ }^{40}$ Earl Stanhope, 'Essay on snuff-taking', Scots Magazine, 1 Jan. 1788.

${ }^{41}$ Goodman, Tobacco in history, pp. 72-85.

${ }^{42}$ See Jerome E. Brooks, Tobacco: its history illustrated by the books, manuscripts and engravings in the library of George Arents, Jr. (5 vols., New York, NY, 1937-52).

${ }^{43}$ See for example, Humourist (London, 1752-87), no. 71, p. 105.

${ }^{44}$ James A. Stuart-Wortley-Mackenzie, Baron Wharncliffe, ed., The letters and works of Lady Mary Wortley Montagu (3 vols., London, 1837), II, p. 425.

${ }^{45}$ On the perceived benefits of sneezing, see Goodman, Tobacco in history, pp. 80-1, 84 .
} 
light, a small quantity of tobacco wrapped up in a 'sealed' paper, and a place or object to spit in - could always be obtained in an alehouse, tavern, or coffeehouse. ${ }^{46}$ But tobacco ranged hugely in quality, and was a constant topic for debate in any company that aspired to style. ${ }^{47}$ Nothing could compare to the comfort of having an ounce or so of one's own favourite ever to hand. In consequence, personal boxes soon became indispensable to tobacco-users. ${ }^{48}$

In Britain, owning a tobacco box became increasingly common from the 1650s: the use of other receptacles, such as pouches, seems to have been rare before the nineteenth century. ${ }^{49}$ By 1649 , middling-sort use of tobacco boxes had increased to such an extent that Charles Hoole thought it necessary to adapt his best-selling text-book Easie entrance to the Latin tongue by offering Latin translations of 'tobacco pipe' (tibus), 'stopper' ( paxolus), and 'box' ( pyxidula) for schoolchildren..$^{50}$ By the early eighteenth century, tobacco boxes had become a predominant feature of lower and middling-sort social life right across Europe and much of colonial America. They were acknowledged to be a vital accessory for any man or woman of real or aspirational fashionwhether they used tobacco or not. ${ }^{51}$

The arbiters of elite tastes and fashion, along with the suppliers and manufacturers of the highest-quality goods, were located in cultural centres such as Paris and London, but insatiable demand across all parts of society encouraged homegrown workshops to produce large numbers of attractive boxes made to set designs in cheaper materials. Workshop- and factory-made boxes commonly incorporated standard 'posy' or verse inscriptions that articulated the sentiments of gifting, or highlighted the obligation of the owner to be a convivial 'good fellow' who was willing to share their tobacco and box in company. Designs included cartouches for the addition of personal initials, details, or dates, which could identify the box with key stages in its owner's life journey. ${ }^{52}$ Sturdy horn boxes (perfect for snuff or tobacco storage) were accessible to all and could be bought for a few pence. However, the range of

\footnotetext{
${ }^{46}$ Barnabe Rich, The honestie of this age (London, 1614), pp. 25-7.

${ }^{47}$ Nuala Zahedieh, The capital and the colonies: London and the Atlantic economy, 1660-1700 (Cambridge, 2010), pp. 197-210. See also Taylor, 'Venting smoke'.

${ }^{48}$ Joseph Fume [pseud.], A paper of tobacco (London, 1839), p. 145; Laufer, 'Introduction of tobacco', p. 38; Lemire, Global trade, pp. 198-201.

${ }^{49}$ The earliest documented box located by the author dates to 1623: TNA, SP 14/142, fo. 92; the earliest extant English boxes I have located date to c. 1630s/40s: wooden box, in shape of a book, decorated with names and signs of London alehouses, https://www.sothebys.com/en/auctions/ ecatalogue/2007/a-celebration-of-the-english-country-house-including-silver-chinese-export-porcelain-n08301/lot.130.html?locale=en; 1652: inscribed silver box, in John Culme, ed., British silver boxes, 1640-1840: the Lion collection (Woodbridge, 2015), pp. 30-1.

${ }^{50}$ Hoole, Easie entrance to the Latin tongue, p. 167.

${ }^{51}$ Stolen boxes frequently contained items such as rings and money, possibly in addition to snuff or tobacco: see, e.g., New-York Journal, or, the General Advertiser, 7 Sept. 1772, p. 669; trial of Mary Atkins for pocket-picking, 15 July 1767 (t17670715-3), and trial of Daniel Tennier for burglary, 17 July 1717 (t17170717-21), both in Old Bailey Proceedings Online (OBPO), www.oldbaileyonline.org; London Journal, no. 113, 23 Sept. 1721, p. 3.

${ }^{52}$ See Angela McShane, 'Belonging and belongings: identity, emotion and memory stored in a tobacco-box', in Dagmar Freist, Sabine Kyora, and Melanie Unseld, eds., Transkulturelle
} 
boxes reported as stolen, or advertised as lost, that belonged to quite ordinary people often represented a considerable monetary outlay, some being valued at ten shillings or more. ${ }^{53}$ This suggests that pragmatic usefulness and affordability were not always the primary motivations behind a purchase.

William King's 'Beau' believed that the social significance of a snuffbox's materiality could not be overemphasized:

[its] largeness ... is a great Recommendation to a Young Gentleman; I knew a Person that got a great Fortune by the Merit of the Spring and Joynt of his Snuff-Box, the Charms of it were irresistible, I would sooner take my Character of a Man from the Engraving, Painting, Enameling of his Snuff-Box, and the Choice of his Orangerie and Bergamott, than from his Discourse and Writings. ${ }^{54}$

In fact, the decoration of inherited tobacco boxes could have real significance for an individual's social position. Samuel Gregge, one of a long line of lawyers, used the heraldic device on his new copper almanac box to claim his distant relationship to an old Cheshire family. ${ }^{55}$ During the herald's visitation of London in 1687, eight men brought engraved silver tobacco boxes as evidence of their family's claim to gentle status. Yet, the culture of heraldic inventions particularly prevalent on tobacco boxes - could lead to embarrassment for heirs, as William Bodington found when he attempted to lay claim to gentility using his father's old box. The herald noted that the Arms from a Silver Tobacco Box, he alledged these to be his Arms and that the Family was of Buckinghamshire, but nothing of his Name to be found in the Visitacions of that County'. ${ }^{56}$ Authentic coats of arms could offer owners some protection from loss, however: for example, when Daniel Manning, vicar of Enfield, was robbed on the highway of money, a watch, and a silver tobacco box engraved with his arms, the robbers returned the box as being too difficult to dispose of. ${ }^{57}$

A tobacco or snuffbox provided an ideal canvas for signalling an owner's wit, humour, leisure pursuits, trade, profession, learning, and leanings. Some carried expressly pious imagery and mottos, although 'graveyard humour' was more typical on extant British boxes. ${ }^{58} \mathrm{~A}$ popular decorative theme was the deleterious effects of intoxicants on the body, including excessive alcohol

\footnotetext{
Mehrfachzugehörigkeiten als kulturhistorisches Phänomen. Räume-Materialitäten-Erinnerungen (Bielefeld, 2019), pp. 59-82.

53 See, e.g., OBPO: trial of Peter Barbey, grand larceny, 10 Oct. 1688 (t16881010-15); trial of Anne Davenant and Margaret Caduggon, grand larceny, 10 Oct. 1711 (t17111010-36); trial of William Giles, robbery, 23 Apr. 1718 (t17180423-28); trial of William Burridge, highway robbery, 23 Apr. 1718 (t17180423-45).

${ }^{54}$ King, Dialogues of the dead, pp. 63-4.

55 Town and McShane, Marking time, pp. 306-7.

${ }^{56}$ T. C. Wales and C. P. Hartley, eds., The visitation of London begun in 1687 (2 pts, London, 2004), I, pp. 336, 54, 108, 142, 203, 212, 214; II, pp. 454-5. Grateful thanks to Tim Wales for these references.

${ }^{57}$ Edmund Calamy, Calamy revised, ed. A. G. Matthews (Oxford, 1934), p. 336. Grateful thanks to Bernard Capp for this reference.

58 See McShane, 'Belonging and belongings', pp. 73-81.
} 
intake, coffee-drinking, and (more rarely) the effects of tobacco itself. ${ }^{59}$ Also popular were depictions of more serious subjects that demonstrated an owner's knowledge of and admiration for worthy historical figures, or indicated their classical education. ${ }^{60}$ But the vast majority of surviving and documented boxes were vehicles for declarations of love and allegiance, whether loyalty to the monarch, the state, a party, or a cause, or, most commonly, personal ties of love and friendship.

The patina and decoration of surviving boxes also reveal the intense emotional ties that bound owners to their tobacco paraphernalia, as both a personal and a social treasure. The exciseman John Cannon took great pride in his tobacco box. In 1725, he recorded that it held ' 4 ounces of tobacco [was] of an oval form \& ... cost $12 \mathrm{~s} 6 \mathrm{~d}$, made of Lidiate Steel well-polished.' His 'cipher for sealing' was 'engraved ... with the motto in Latin \& the place of my nativity \& year of the Lord when I had it done' - a fascinating case of a date relating to the life journey of the box, rather than the owner. Cannon also noted the other decorations, including 'doves and heads adorned on the sides; at the bottom a scollop with leavidge \& foldings, on the crest two tulips, two pipes crosswise \& a Black's head with a Pipe smoaking'. When, in 1738, his daughter and a friend gifted him a new round box made of silver, he had it engraved in the same way, with his seal, motto, and date, and drew a picture of the lid in his diary, immediately adjacent to the fulsome description of his old box. ${ }^{61}$ A widespread sense of appreciation for the emotional significance embedded in boxes encouraged people from across the social spectrum to adopt, adapt, and reinscribe second-hand boxes (whether they were gifted, inherited, or purchased). ${ }^{62}$

The remarkable tobacco box seen in Figure 2 exhibits several of these categories of meaning. Two dated inscriptions, engraved by different hands in 1670 and 1700 , suggest that the box had changed owners, though we do not know if this came about through ties of family or friendship, or by secondhand purchase. Inscribed with the ownership initials 'I P', the lid depicts various woodworking tools and barrels, suggesting the cooper's trade. Running dogs on the edge, and cockerels on the lid, perhaps indicate the owner's favoured leisure pursuits. In a shift of scene, the base depicts a pipe-smoking King Charles II, marking the owner's allegiance to both royalty and intoxicant. In fact, Charles II is not known to have smoked, but his figure was often used as

\footnotetext{
${ }^{59}$ See, e.g., Wellcome Collection/Science Museum Loan Objects: A125067, https://collection. sciencemuseumgroup.org.uk/objects/co157621/snuff-box-england-1771-1830-snuff-box; A642700, https://collection.sciencemuseumgroup.org.uk/objects/co159472/snuff-box-europe-1831-1900-snuffbox; https://www.bonhams.com/auctions/11590/lot/241/.

${ }^{60}$ See, e.g., Wellcome Collection/Science Museum Loan Objects: A642712, https://collection. sciencemuseumgroup.org.uk/objects/co159484/wooden-snuff-box-cylindrical-painted-with-a-portsnuff-boxes; A642697, https://collection.sciencemuseumgroup.org.uk/objects/co159469/woodensnuff-box-cylindrical-painted-with-a-port-snuff-boxes.

${ }^{61}$ Money, ed., Chronicles of John Cannon, p. 181, n. 386, and pl. 6.

${ }^{62}$ McShane, 'Belonging and belongings', pp. 79-80; Town and McShane, Marking time, pp. 310, 318.
} 


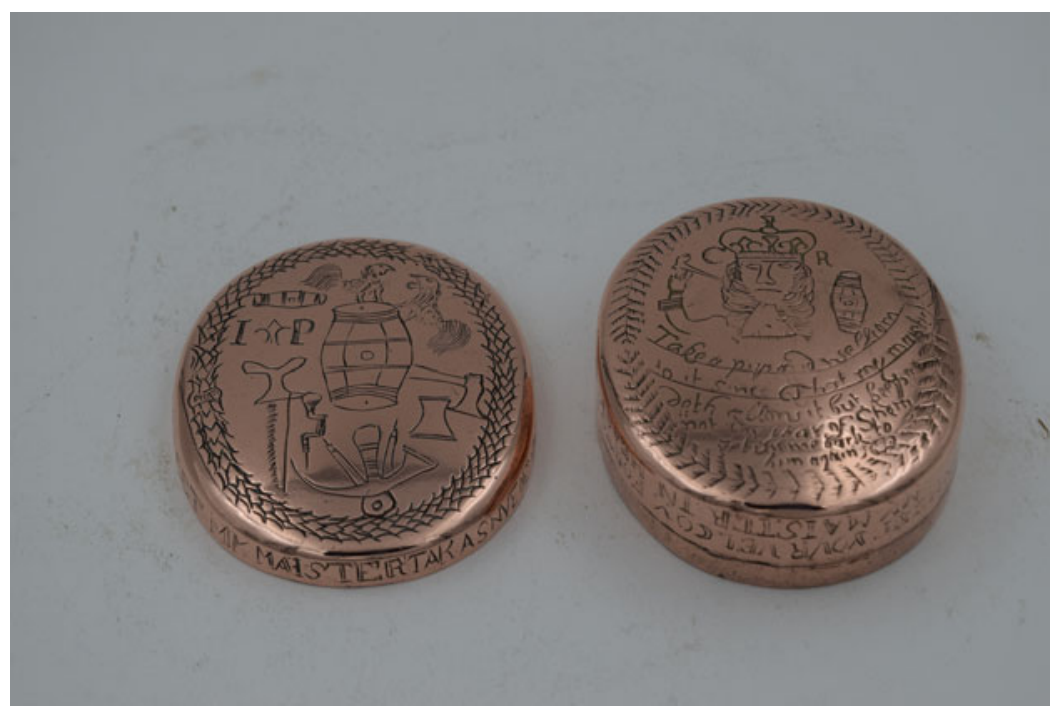

Fig. 2. Copper tobacco box, inscribed 'I. P.; ' 1670 '; ' 1700 '; 'Fill your pip but kep me not stil and let my maister tak a snuf of your mil'; 'My in meat your velcom for to taist but return me back to my maister in heast'; 'Take a pyp and wellcom to it / since that my maister doth allow it, / but keep me not for fear of Shem / retun me back to him again'.

Source: Image courtesy of the Bryan Collection. Photo: Tom Gleason.

a model for tobacco rammers. ${ }^{63}$ A powerful emotional attachment to the box itself is conveyed by three mottos that directly address the owner's acquaintances. One demands reciprocity, offering pipe tobacco in return for snuff: 'Fill your pip[e] but ke[e]p me not stil[1] and let my maister tak[e] a snuf[f] of your mil'. A second combines invitation with anxious exhortation: 'My in meat your velcom for to taist [taste] but return me back to my maister in heast [haste]'. The third merges invitation and warning: 'Take a pyp and wellcom to it / since that my maister doth allow it, / but keep me not for fear of Shem [shame] / retu[r]n me back to him again'.

Intrinsic to these multiple expressions of anxiety about loss were the inherent risks in social obligations that sent personal tobacco paraphernalia into motion around a company. When losses occurred, people would go to considerable lengths to recover their goods. One man terrorized an alewife in Chester, demanding entry to her alehouse late at night because he believed he had lost his tobacco 'rammer' there. ${ }^{64}$ Another man brought his friend to court after his silver rammer went missing. The friend excused himself by claiming he had taken it in jest. ${ }^{65}$ In one extreme case, in seeking revenge

${ }^{63}$ Town and McShane, Marking time, p. 302.

${ }^{64}$ Deposition of Jane Poole of Chester, widow, 11 May 1685, Cheshire Archives and Local Studies ZQSF/83/50, reference courtesy of the Intoxicants and early modernity database, https://www.intoxicantsproject.org/publications/database/.

${ }^{65}$ Norfolk Record Office C/S 3/53a, reference courtesy of the Intoxicants and early modernity database. 
for the loss of a snuffbox that had been given to her by a former lover, Mary Price, a servant woman, murdered the child who had taken it. ${ }^{66}$

The vulnerability of tobacco boxes to crime and mishap was recorded sympathetically in the press. Periodicals recounted dramatic stories of thieves who brutally demanded boxes from both male and female victims, some of whom were unable to bear being separated from either box or snuff. In 1721, the highwayman Richard James stole a lady's silver snuffbox but returned some of her snuff wrapped 'in a paper' at her request; but in 1751, the Rev. Mr Noble failed to persuade the men who had robbed him to return his beloved 'old Steel Tobacco box', which 'had been long in his possession'.67 Newspapers carried hopeful adverts calling for the return of lost boxes, as in 1710, when a man offered 'a guinea reward, and no questions ask'd' on the return of his treasured tortoiseshell snuffbox to the Young Man's Coffee House in Charing Cross. ${ }^{68}$ Literary sources likewise highlighted the emotional significance of boxes. For example, in Cibber's Love makes a man: or, the fop's fortune, while supposedly searching for his kidnapped wife-to-be, the foppish character Claudio shows far more concern for the loss of a snuffbox gifted to him by a duchess. He plans to have it advertised in the gazette and cried in the street, not in hopes of having it recovered, but so that she will know how much it mattered to him. ${ }^{69}$ One periodical told a melodramatic story of how a woman with two suitors disregarded the vital importance of a box given in love - a 'moral tale' that ultimately (and inevitably) ended in death and disappointment for all concerned. ${ }^{70}$

\section{IV}

Every tobacco box represented an extraordinary nexus of global trade and transaction. It might incorporate German brass, Swedish iron, American silver, Indian ivory, South American woods, or Caribbean tortoiseshell. Even if made using locally sourced materials, such as bone, horn, or tin, boxes were designed to be filled with tobacco products that originated from the New World. As Lauren Working has shown, indigenous practices strongly influenced the consumption of tobacco in the earlier part of the seventeenth century. ${ }^{71}$ In the eighteenth century, colonial production systems - including images of ports, plantations, and enslaved producers - were frequently depicted on tobacco containers, in treatises, and in commercial advertising. In the meantime,

\footnotetext{
${ }^{66}$ OBPO: trial of Mary Price for murder, 9 Jul. 1718 (t17180709-36), with ordinary's account, 6 Aug. 1718 (OA17180806).

${ }^{67}$ OBPO: ordinary's account, 23 Oct. 1721 (OA17211023); Covent Garden Journal, 27 (1752), p. 3.

${ }^{68}$ Daily Courant: 14 Dec. 1710; 27 Aug. 1708; 23 Jan. 1707; 9 June 1709; 7 Feb. 1711; 12 Mar. 1711. Post Boy: 30 Dec.-1 Jan. 1708-9; 21-24 Oct. 1710. Post Man and the Historical Account: 30 Dec.-1 Jan. 1708-9; 11-13 Jan. 1711. Evening Post: 20-23 Jan. 1711.

${ }^{69}$ Colly Cibber, Love makes a man, or the fop's fortune (London, 1701), p. 30.

70 'The snuff box: a moral tale', Norwich Packet and the Connecticut, Massachusetts, New-Hampshire, and Rhode-Island Weekly Advertiser, 11-18 Nov. 1773, p. 4.

${ }^{71}$ Lauren Working, 'Tobacco and the social life of conquest in London, 1580-1625', in this issue; see also eadem, The making of an imperial polity: civility and America in the Jacobean metropolis (Cambridge, 2020), chs. 4 and 5; Lemire, Global trade, ch. 5.
} 
however, tobacco- and especially snuff-taking had succumbed to what Goodman has called the 'Europeanization' of goods and ideas: 'an ongoing process of appropriation, development and definition which ... began in the sixteenth century and reached its apogee in the eighteenth century'. ${ }^{72}$

While the nomenclature of some tobacco products, such as 'Brazil' (which travelled to North America, via Lisbon and London) or 'Virginia', retained traces of their geographical origins, it was more common for both products and paraphernalia to be divorced from their native contexts. Colonial newspapers announced the arrival of 'Bristol short' and 'London long' pipes to smoke from, while snuff and the snuffbox were almost entirely 'Europeanized'. ${ }^{73}$ Both British and British-American consumers preferred the standardized tastes and textures of snuff products with European identities, which were a sophisticated mix of leaf, perfume, and herbs. ${ }^{74}$ 'Scotch snuff', a mild and dry variety, was a particular favourite with ladies on both sides of the Atlantic. ${ }^{75}$ Though substantially consisting of Virginian tobacco, it was milled and mixed in Glasgow, and brought to America via London, where its arrival was joyfully announced by the papers. ${ }^{76}$ Even when manufactured in America, the most successful North American enterprises were run by Scottish immigrants, and retained the 'Scotch' name. ${ }^{77}$ By the early 1800s, this Scottish identity had been further materialized through box design and decoration. Standardized boxes (perhaps intended mainly for women) were cheaply covered with tartan-printed paper, while Scottish-style horn-shaped 'mulls' (probably for men) also became popular. ${ }^{78}$

Although, for a brief period, it was deemed unacceptable to smoke in New England 'ordinaries', to prevent long stays and excess drinking, it was not long before tobacco boxes operated practically and socially within early American white society in very similar ways to those in Britain and in Europe. ${ }^{79}$ As in Britain, the design, shape, and fashionable use of tobacco and snuffboxes in colonial America was proscribed and policed by European trendsetters. Before the revolution, jewellers in Boston, Philadelphia, and Charleston

\footnotetext{
${ }^{72}$ Jerome Goodman, 'Exitantia: how Enlightenment Europe took to soft drugs', in Goodman, Lovejoy, and Sherratt, eds., Consuming habits, pp. 126-47, at p. 131.

${ }^{73}$ See, e.g., Boston News-Letter, 23-30 Apr. 1716; 23 Dec. 1742; 17 Jul. 1760.

${ }^{74}$ See, e.g., Charles Lillie, The British perfumer, ed. Colin Mackenzie (2nd edn, London, 1822).

${ }^{75}$ Anon., Snuff and snuff-takers (London, 1846), p. 25.

${ }^{76}$ See, e.g., Boston News-Letter, 7-14 Oct. 1742; Charleston City Gazette and Advertiser, 11 Dec. 1799.

${ }^{77}$ Michael Hoberman, "'Under their captivity \& dispersion": the story of Boston's first Jewish business venture', Early American Studies, 103 (2012), pp. 600-29; Gallagher, 'Snuff is enough'.

${ }^{78}$ See, e.g., Wellcome Collection/Science Museum Loan: A19216, https://collection.sciencemu seumgroup.org.uk/objects/co156877/wooden-snuff-box-mauchline-scottish-tartan-design-snuffbox; A637487, https://collection.sciencemuseumgroup.org.uk/objects/co158258/snuff-box-woodentartan-with-laurencekirk-hinge-snuff-boxes; A637483, https://collection.sciencemuseumgroup. org.uk/objects/co158254/black-lacquered-snuff-box-hinged-lid-tartan-pape-snuff-boxes. To date, I have only found men's names inscribed on mulls.

${ }^{79}$ Dean Albertson, 'Puritan liquor in the planting of New England', New England Quarterly, 23 (1950), pp. 477-90; Madeline Siefke Estill, 'Colonial New England silver snuff, tobacco, and patch boxes: indices of gentility', in Jeannine Falino and Gerald W. R. Ward, eds., New England silver and silversmithing, 1620-1815 (Boston, MA, 2001), pp. 44-60.
} 
invariably advertised boxes for sale that had been obtained through London sources. Those who made their own boxes (or who adapted and personalized imported ones) claimed that they had been trained in London, or that they were following the latest European fashions. ${ }^{80}$ The same periodicals that informed and influenced tobacco praxis in Britain were reprinted for an American audience. Books and magazine digests were imported wholesale, or were privately obtained from Europe by proxies, while city newspapers regularly filched content from the London press, especially the crime reports. These may inadvertently have advertised the ubiquity, range, and high value of boxes regularly stolen from quite ordinary Londoners, perhaps stoking desire in their American readers. In other respects, too, American habits mirrored those of Britain: for example, the ubiquity of ownership, the obligation to share, and the sensibilities behind gifting practices. Americans, keen to display their social status, had family crests inscribed on their boxes - a practice that continued even after the revolution - while adverts describing lost boxes, of sentimental as well as material value, regularly appeared in the papers. ${ }^{81}$

Yet, while colonial American tobacco praxis was undoubtedly inflected through British and European manners, taste, and style, there were some important distinctions. The centrality of tobacco to the North American economy meant that it was much more likely to be used as currency in exchange for services or goods, or for payment of gambling debts, than in Britain ${ }^{82}$ City shopkeepers occasionally advertised a willingness to accept tobacco or snuff as payment, while at least one inveterate snuff-taking midwife, who worked for the local community in Oxford, Massachusetts, was often given snuff in lieu of money. ${ }^{83}$

Modes of typical consumption also differed from the British context, requiring further gradations in social decorum not dealt with by the British press. Whereas the vast majority of Europeans either smoked or snuffed, chewing tobacco was an everyday behaviour for all 'sorts' of American men. ${ }^{84}$ Travellers observed how the chewing of tobacco, and the energetic spitting it entailed, typically accompanied men's work and social interactions when outdoors. ${ }^{85}$ Indeed, stereotypical images of 'chawing' Americans appeared in a variety of satirical contexts. ${ }^{86}$ The practice was not deemed respectable for

\footnotetext{
${ }^{80}$ See, e.g., Boston Gazette: 28 Nov. 1737; 5 Dec. 1737; 7 May 1754; 5 July 1762; 11 Nov. 1765. Boston News-Letter: 17 May 1746; 15 May 1760; 14 May 1764; 27 Sept. 1764; 28 Apr. 1768; 9 Jan. 1772.

${ }^{81}$ Bayard, Travels of a Frenchman, p. 128. See, e.g., John Coney silver snuffbox, c. 1710. Engraved: Wentworth arms and 'En dieu est tout' on scroll. Yale University Art Gallery, museum no. 1945.124a-b, https://artgallery.yale.edu/collections/objects/44746.

${ }^{82}$ Mary McKinney Schweitzer, 'Economic regulation and the colonial economy: the Maryland Tobacco Inspection Act of 1747', Journal of Economic History, 40 (1980), pp. 551-69, at pp. 563-4; T. H. Breen, 'Horses and gentlemen: the cultural significance of gambling among the gentry of Virginia', William and Mary Quarterly, 34 (1977), pp. 239-57.

${ }^{83}$ Laurel Thatcher Ulrich, A midwife's tale: the life of Martha Ballard, based on her diary, 1785-1812 (New York, NY, 1991), p. 137.

${ }^{84}$ Laufer, 'Introduction of tobacco', pp. 140-2; Goodman, Tobacco in history, pp. 67-8.

${ }^{85}$ Bayard, Travels of a Frenchman, p. 146.

${ }^{86}$ See, e.g., Donald L. Fennimore, 'Metalwork', American Art Journal, 7 (1975), pp. 93-106, at p. 106. Commentators offer differing interpretations regarding which nationalities or trades are being
} 
women, for the domestic sphere, or for polite company. ${ }^{87}$ Pipe-smoking and snuff-taking were considered to be more mannerly behaviours, though here (as elsewhere) acceptability depended on context. As in Europe, pipe-smoking was assumed to be distasteful to polite women, but for some communities such as the Quakers of Philadelphia - it was a respectable domestic activity for both sexes, while 'smoking a pipe', usually after the afternoon tea meal, presented an ideal opportunity to draw companies of friends together in the home. ${ }^{88}$

There was a further marked difference in the gendering of tobacco-box identities. Personal papers, the press, and criminal records demonstrate that, by the mid-eighteenth century, snuffboxes had become standard accessories for men and women of all social sorts on both sides of the Atlantic. These same records also make very clear that there was a strong culture of mutual box-gifting between and among the sexes. Yet, although many surviving boxes explicitly record male ownership and male-to-male statements of gifting and friendship, the British material record provides little explicit sign of female ownership or gifting. An abundance of objects survive that are decorated with hearts and flowers, courtship scenes, love-posies, or portraits of younger and older men and women, some incorporating pairs of unmatched initials, any of which might imply women as either givers or receivers. But finding first or full names of women on British boxes is extraordinarily rare: just seven have been located so far that explicitly record a female name, compared to more than three times that number on American boxes. ${ }^{89}$ The anonymizing of British women's tobacco habits contrasts starkly with American conventions, where female tobacco-taking and ownership of boxes were celebrated in a much more explicit way. Moreover, personal correspondence reveals how American women's proxy shopping, gifting, and judicious distribution of boxes, tobacco, and snuff played a central role in the creation and maintenance of family and friendship networks both at home and across the Atlantic. ${ }^{90}$

This distinctively gendered aspect of American tobacco praxis may offer a different perspective on the role of intoxicants in the creation of a united American identity, both before and after the revolution. T. H. Breen has persuasively argued that a shared, anglicized consumer culture - and especially the centrality of tea to domestic routines across the thirteen states of colonial America - enabled them to build an 'imagined community'. The boycott of

stereotyped by the chawing, smoking, and snuffing characters - see, e.g., https://wellcomecollection.org/works/rtnyfdrn/images?id=ddwwga9n.

${ }^{87}$ See, e.g., Howard B. Rock, 'A woman's place in Jeffersonian New York: the view from The Independent Mechanic', New York History, 63 (1982), pp. 434-59, at p. 445.

${ }^{88}$ See McShane, 'Bad habits', p. 33; Rock, 'A woman's place', pp. 444-50.

${ }^{89}$ These are listed and discussed in McShane, 'Bad habits', pp. 45-6, 55.

${ }^{90}$ See, e.g., letters from Abigail Bilhah Levy Franks, in Leo Hershkowitz and Isidore S. Meyer, eds., The Lee Max Friedman collection of American Jewish colonial correspondence: letters of the Franks family, 1733-1748 (Waltham, MA, 1968), pp. 60, 77, 88, 91, 97; on colonial letter-writing and gifting, see also Sarah M. S. Pearsall, Atlantic families (Oxford, 2008); for a fuller discussion of American and British women's tobacco habits, see McShane, 'Bad habits'. 
imported British 'baubles' helped to rally and unite Americans in the interests of the common cause, leading to the valorization of homespun clothing and alternative drinks. ${ }^{91}$ These actions also politicized American women, dubbed 'daughters of liberty', who were responsible for managing the domestic consumption of tea and textiles. ${ }^{92}$

Though Americans maintained their foothold in the European 'social communication network' delineated by tobacco, in the collective imagination tobacco was repossessed during the revolution as the prime commodity of an independent America. ${ }^{93}$ Tobacco not only helped to finance the American War of Independence, but revolutionaries also appropriated and exploited the material culture of tobacco for their own political ends by co-opting the tobacco box into their propaganda campaigns. Cheaper lacquer and papier-mâché tobacco boxes (many made in Britain) were used to disseminate images linking French and American interests, or portraits of revolutionary heroes, such as Benjamin Franklin, all over Europe. ${ }^{94}$ Moreover, the European tradition of towns giving 'freedom boxes' to important figures took on a new meaning in the American context. ${ }^{95}$

At the same time, the early republic sought to forge a distinctly American style, taking a moral stance on overly luxurious consumptive behaviours as un-American, smacking of European elitism and corruption. In a wartime letter to his daughter, Benjamin Franklin (who admired clever snuffbox designs) described how his face was appearing on objects all over Europe, but also expressed disapproval of his daughter's request to send her luxuriously fashionable trinkets. ${ }^{96}$ John Adams expressly refused to be 'bought' with the offer of 'gold boxes' by European diplomats - an instinct that was later enshrined in the constitution. ${ }^{97}$ American tobacco boxes were to be locally

\footnotetext{
${ }^{91}$ T. H. Breen, "'Baubles of Britain": the American and consumer revolutions of the eighteenth century', Past \& Present, 119 (1988), pp. 73-104.

${ }^{92}$ See, e.g., Laurel Thatcher Ulrich, The age of homespun (New York, NY, 2001); Mary Beth Norton, 'The evolution of white women's experience in early America', American Historical Review, 89 (1984), pp. 593-619.

${ }^{93}$ See the useful summary in J. F. Bosher, 'Review of Jacob M. Price, France and the Chesapeake: a history of the French tobacco monopoly 1674-1791 and of its relationship to the British and American tobacco trades (2 vols., Ann Arbor, University of Michigan Press, 1973)', Canadian Historical Review, 57 (1976), pp. 93-5; Roland M. Baumann, 'Philadelphia's manufacturers and the excise taxes of 1794: the forging of the Jeffersonian coalition', Pennsylvania Magazine of History and Biography, 106 (1982), pp. 3-39.

${ }^{94}$ E. McClung Fleming, 'Early American decorative arts as social documents', Mississippi Valley Historical Review, 45 (1958), pp. 276-84, at pp. 279-80; see also Philadelphia Museum of Art, museum no. 1899-1032,a: https://www.philamuseum.org/collections/permanent/123873.html?mulR=265213797| 222; Skinner Antiques, https://www.skinnerinc.com/auctions/2482/lots/45.

${ }^{95}$ Charles O. Cornelius, 'Early American jewelry', Metropolitan Museum of Art Bulletin, 21 (1926), pp. 99-101, at p. 101; Edwin J. Hipkiss, 'Some early American objects of gold', Bulletin of the Museum of Fine Arts, 44, no. 257 (1946), pp. 63-6.

${ }^{96}$ Benjamin Franklin to Sarah Bache, 3 Jun. 1779, Passy, printed in William Temple Franklin, ed., The private correspondence of Benjamin Franklin, LL.D. F.R.S. \&c. (2nd edn, 2 vols., London, 1817), I, pp. 42-5.

${ }^{97}$ See Robert Ralph Davis, 'Diplomatic gifts and emoluments: the early national experience', Historian, 32 (1970), pp. 376-91.
} 
made and to be spare and uncluttered in design and decoration: silver was allowable, but gold was not. ${ }^{98}$ A strong preference for locally painted portrait lids, not just of great revolutionaries but of all social sorts, emerged. ${ }^{99}$ These changes can partly be tracked through newspaper adverts. Snuffboxes had been included in the first boycott campaign in the early 1770s, and there appears to have been a brief cessation of advertisements for imported trinkets. After the revolution, though jewellers' advertisements still highlighted attention to French fashions, they emphasized the American production of their goods, while home-grown artists advertised tobacco-box portrait-painting services for middling-sort Americans. ${ }^{100}$

As 'daughters of liberty', whose role in managing domestic consumption had been so important to the war, American women's relationship to the national product was uniquely highlighted during and after the revolution. While, on the one hand, tobacco and snuffboxes were used as a way of celebrating American independence and identity, on the other, American women's tobacco-taking became a matter of family pride. Women's American-made snuffboxes became inextricably linked with the construction of the liberated American family, and moreover offered a canvas for the expression and experience of American sensibility. ${ }^{101}$ American women's snuffboxes could be used to record dynastic connections, especially through the practice of post-mortem inscriptions, which were added as boxes passed down through the family: as, for example, the late seventeenth-century silver snuffbox shown in Figure 3, which was inscribed 'MB Ex Dono to EB' and, in a different hand, 'Eliza Brame' and (General) 'John Glover'. ${ }^{102}$ Engraved commemorations were augmented by full-scale portraits in which women held snuffboxes that had been gifted to them at key moments in their family's life cycle. ${ }^{103}$ Even

${ }^{98}$ R. T. H. Halsey, 'Some Boston silversmiths of colonial date', Burlington Magazine for Connoisseurs, 9, no. 42 (1906), pp. 419-25.

${ }^{99}$ Carrie Rebora Barratt, Faces of a new nation, special issue of Metropolitan Museum of Art Bulletin, 61 (2003), pp. 1-64.

${ }^{100}$ See, e.g., Penna Packet, 26 Apr. 1793; Maryland Gazette, 15 Nov. 1792; Aurora, 16 Mar. 1798 and 26 Nov. 1799; Federal Gazette, 2 Jul. 1794; Charleston City Gazette and Advertiser, 25 Jan. 1794.

${ }^{101}$ See, e.g., G. J. Barker-Benfield, Abigail and John Adams: the Americanization of sensibility (Chicago, IL, 2010).

${ }^{102}$ In the online catalogue (https://artgallery.yale.edu/collections/objects/6395) this object is described as a patch box, but it would have been too deep to be suitable for patches; see also https://artgallery.yale.edu/collections/objects/37853, a snuffbox engraved 'Robert Calef to Mary Calef 1748' (Obadiah Hussey married Mary Calef in 1748) and later engraving 'Lucretia Strasey[?] / L.H. 1748 / Box'. See the fuller discussion of these objects in McShane, 'Bad habits', pp. 41-2, 44-5.

${ }^{103}$ See, e.g., John Hesselius, Portrait of Ann Fitzhugh Rose, Stafford County, Virginia, holding snuff box, 1771, Colonial Williamsburg, museum no. 1989-338,A\&B, https://emuseum.history.org/objects/ 31972/portrait-of-ann-fitzhugh-rose-mrs-robert-rose17211789;jsessionid=A614CCEEFCB389389CDC EABA2701541F; Pieter Vanderlyn (attrib.), Wedding portrait of Elizabeth 'Betje' Van Dyck Vosburg holding snuffbox engraved with initials of herself and her husband, New York, c. 1725, https://www. skinnerinc.com/auctions/2585B/lots/216; Pieter Vanderlyn, Wedding portrait of Annetje Kool, holding silver snuff box engraved with her initials A K, Ulster County, NY, c. 1740, http://www.afanews.com/ articles/item/737-inspired-traditions-selections-from-the-jane-katcher-collection-of-americana\#. XcQ34i2cYWq. 


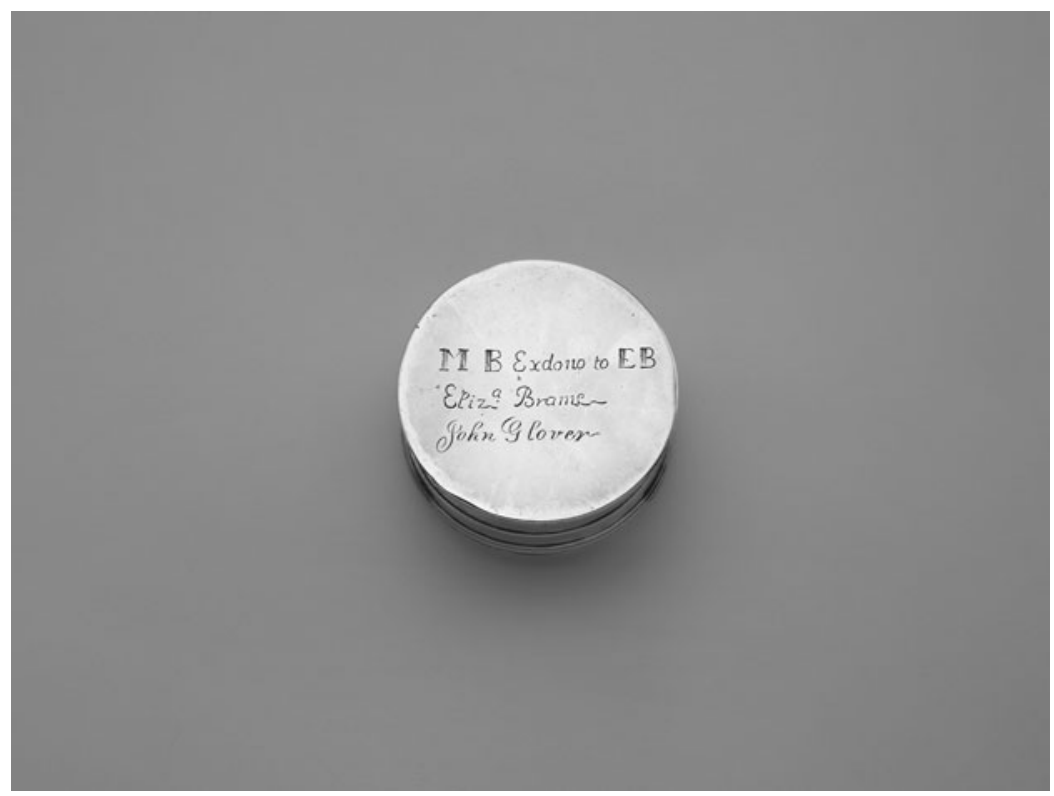

Fig. 3. Silver box, c. I700-10, possibly by Edward Webb (I666-17I8); inscribed 'MB Ex Dono to EB' I 'Eliza Brame' / 'John Glover'.

Source: Photograph Courtesy of Yale University Art Gallery.

Betsy Ross, who sewed the first American flag, was, and is, commemorated with a variety of domestic objects, including her silver snuffbox. ${ }^{104}$

\section{V}

This article has argued that, in their 'doings and sayings', their materiality, inscriptions, and patina, and through the consumer choices and emotional exchanges to which they bear witness, snuff- and tobacco boxes provide a key nexus for understanding the interconnected, routinized elements of tobacco praxis. ${ }^{105}$ As carriers of motivational knowledge, skill, and social know-how, tobacco and snuffboxes themselves incited physical and emotional responses and activities. They not only played a central role in displaying fellowship, dexterity, fashionability, and taste but also served to create and reproduce white middling-sort identities on both sides of the Atlantic. Yet, the embedding of tobacco-taking in national and personal identity-building came at a terrible price to humankind: as a Gentleman's Magazine article of 1746 presciently remarked, the golden box that Pandora brought from heaven,

${ }^{104}$ Marla R. Miller, Betsy Ross and the making of America (New York, NY, 2010), pp. 8, 341, 345.

105 Theodore R. Schatzki, Social practices: a Wittgensteinian approach to human activity and the social (Cambridge, 1996). 


\section{'said to have contain'd all manner of mischiefs and deaths', was surely a snuffbox. ${ }^{106}$}

Acknowledgements. This article forms part of Intoxicants and early modern European globalization: spaces, practices, material culture, a special issue resulting from a workshop series, held in 2017 at the Victoria and Albert Museum and in 2018 at the Beinecke Library, Yale University. I am grateful to the editors and readers of the Historical Journal, to my ESRC/AHRC 'Intoxicants \& Early Modernity Project' colleagues, Phil Withington, James Brown, and Tim Wales, to Dr Kathryn James of Yale's Beinecke Library, and also to Prof. Bernard Capp, Dr Elaine Tierney, Dr Tim Reinke-Williams, and Dr Lauren Working, for their advice and support.

Funding Statement. The workshop series at the Victoria and Albert Museum was funded by the ESRC 'Intoxicants \& Early Modernity Project'. Research for the article was supported by an American Friends of the V\&A research fellowship (2016), a V\&A/YCBA exchange fellowship (2017), and a week at Yale, generously funded by the Wellcome Collection (2018).

\footnotetext{
${ }^{106}$ Sylvanus Urban, 'On a young lady's desiring the author to return a snuff box', Gentleman's Magazine, 16, 1 Dec. 1746, p. 662.
}

Cite this article: McShane A (2022). Tobacco-Taking and Identity-Making in Early Modern Britain and North America. The Historical Journal 65, 108-129. https://doi.org/10.1017/S0018246X21000273 